\title{
KONSERVASI KAYU GAPURA MAJAPAHIT DI KABUPATEN PATI
}

\author{
Dwi Astuti (Balai Pelestarian Cagar Budaya Yogyakarta), Nahar Cahyandaru (Balai Konservasi Borobudur), \\ Mujiharja (Balai Pelestarian Cagar Budaya Yogyakarta) \\ E-mail : n.cahyandaru@gmail.com
}

\begin{abstract}
Abstrak: Naskah kajian ini disusun dalam rangka kegiatan konservasi Gapura Majapahit di Pati. Kajian ini disusun dengan maksud sebagai bagian penting dalam tahap tindakan konservasi yang menurut Undang-undang No. 11 tahun 2010 tentang Cagar Budaya harus dapat dipertanggungjawabkan secara ilmiah. Tujuan dari kajian ini adalah untuk mengetahui berbagai permasalahan konservasi yang terjadi, mengetahui efektivitas metode yang dipilih beserta dampak negatif yang mungkin muncul, serta mengevalusi pelaksanaan konservasi dan hasil-hasilnya.

Tindakan konservasi Gapura Majapahit telah dilaksanakan menggunakan tahapan kerja yang sesuai. Permasalahan konservasi yang dianalisis meliputi keberadaan sisa-sisa bahan konservan terdahulu, noda lilin dari lebah, bekas penanganan kayu keropos, pertumbuhan organisme, dan vandalisme. Metode konservasi yang digunakan telah dipilih dan diuji untuk memastikan efektivitas serta tidak menimbulkan dampak negatif. Konservasi dengan bahan-bahan kimia yang digunakan diharapkan dapat bertahan lebih lama sehingga tidak perlu pengulangan-pengulangan yang terlalu sering. Tindakan rutin yang diharapkan terus dilakukan ke depan adalah pembersihan secara manual terhadap permukaan dan lingkungan sekitarnya. Rekomendasi yang perlu disampaikan untuk tindakan ke depan adalah perlunya dilakukan tindakan konservasi dan penataan koleksi lepas. Selain itu juga perlu dilakukan perkuatan bagian ornamen yang miring, karena dikhawatirkan dalam jangka panjang akan semakin miring dan membahayakan.
\end{abstract}

Kata kunci : Konservasi kayu, Gapura Majapabit, Analisis kerusakan, Pengujian metode

Abstract: This study prepared for the purposes of conservation Majapahit wooden gate in Pati. The study was composed with the purpose to take part in an important part iof the conservation stages, in accordance with the Law No. 11 year 2010 concerning Cultural Haritage that all conservation activities must be scientifically justified. The objective of this study was to determine the various conservation problems that occur, examine the effectiveness of the methods selected along with the negative impacts that may arise, as well as evaluating the implementation of conservation and its results.

Majapahit wooden gate conservation measures have been implemented using the appropriate stages of work. Conservation problems analysed include the presence of remnants of the previous conservant material, stain wax from the bees, the former work of decayed wood, the organism growth, and vandalism. Conservation methods used have been selected and tested to ensure effectiveness and does not cause negative impacts. Conservation with the chemicals used are expected to last longer so it does not need repetition too often. Routine actions are expected to continue in the future by manually cleaning of the surface and surroundings area. Recommendations need to be submitted for next action is the need for conservation measures and managing the movable collection detached from the structure. Retrofitting the ornament sloping section is also needed to avoid further sloping that could be dangerous in the future.

Keyword : Wood conservation, Majapahit gate, Deterioration analysis, Field testing

\section{PENDAHULUAN}

\subsection{Latar Belakang}

Cagar Budaya Gapura Majapahit merupakan sebuah pintu gerbang yang terbuat dari kayu berukir. Ukiran yang ada menggambarkan cerita Panji dengan ragam hias yang sangat indah. Gerbang ini dipercaya sebagai bekas gerbang Kaputren Majapahit yang dahulu dibawa ke Pati. Saat ini tersimpan dengan baik di tempatnya yang secara administratif termasuk dalam wilayah Desa Rendole, Kecamatan Margorejo, Kabupaten Pati. Setelah berada di Pati, pintu gerbang ini tidak dipindahkan lagi hingga saat ini.
Menurut catatan yang ada, pintu gerbang ini pernah mengalami tindakan perbaikan oleh Bupati Pati saatitu (sekitar tahun 1950an) dengan mengganti beberapa bagian kayu yang lapuk. Selanjutnya pada tahun 1980an, gerbang ini ditempatkan pada lokasi dengan bangunan pelindung. Bangunan tersebut tidak berdinding (terbuka) namun kondisi atapnya cukup baik untuk melindungi. Kondisi gerbang yang aslinya beratap, kemudian tidak dikembalikan secara utuh karena banyak komponen atap yang sudah rusak atau lapuk. Saat ini bagian-bagian atap disimpan di dekat lokasi gerbang. Setelah dilakukan 
pelindungan dengan bangunan baru tersebut, tercatat pernah sekali dilakukan upaya konservasi (tahun 90an) untuk mengatasi berbagai permasalahan kerusakan dan pelapukan yang terjadi.

Kajian ini disusun dengan maksud sebagai bagian penting dalam tahap tindakan konservasi yang menurut Undang-undang No. 11 tahun 2010 tentang Cagar Budaya harus dapat dipertanggungjawabkan secara ilmiah. Tindakan konservasi yang dilakukan diawali dengan analisis terhadap permasalahan konservasi, pemilihan dan pengujian metode yang akan digunakan, pelaksanaan tindakan, dan evaluasi. Tujuan dari kajian ini adalah untuk mengetahui berbagai permasalahan konservasi yang terjadi, mengetahui efektivitas metode yang dipilih beserta dampak negatif yang mungkin muncul, serta mengevalusi pelaksanaan konservasi dan hasil-hasilnya. Manfaat yang diharapkan dari kajian ini adalah dapat memberikan gambaran tahapan-tahapan yang perlu dilakukan dalam melaksanakan tindakan konservasi agar dapat dipertanggungjawabkan secara ilmiah.

\subsection{Tinjauan Pustaka}

Kayu merupakan bahan yang terbaik untuk digunakan sebagai bahan dalam pembuatan benda-benda budaya, baik berupa benda fungsional maupun benda untuk mengekspresikan rasa seni. Benda-benda budaya mengandung nilai luhur dalam aspek-aspek: budaya, sosial, arkeologi, sejarah, ilmu pengetahuan dan teknologi serta ekonomi.

Dalam melaksanakan tindakan konservasi, perlu dilakukan strategi konservasi yaitu skenario yang merupakan cetak biru di dalam kerangka melakukan aktivitas pelestarian benda cagar budaya. Di dalamnya berisi deskripsi tentang berbagai bentuk aktivitas yang meliputi pemeliharaan, perawatan, dan pemugaran. Aktivitas pemeliharaan dilakukan dengan membersihkan koleksi dari kotoran debu. Aktivitas perawatan dilakukan dengan mengusahakan agar komponen penyusun cagar budaya berbahan kayu berada pada posisi yang normal, sehingga fungsi komponen dapat diaktualisasikan sebagaimana semula. Aktivitas pemugaran dilakukan dengan membangun kembali koleksi sesuai dengan kondisi yang asli. Oleh karena itu, aktivitas pemugaran dilakukan terhadap komponen koleksi mengalami kerusakan yang cukup parah (Suranto, 2015).

Salah satu tahap dalam konservasi kayu adalah pengawetan. Pengawetan bertujuan untuk memperpanjang umur pemakaian kayu, sehingga kayu dapat bertahan untuk waktu yang lama tanpa penggantian komponen yang terlalu sering. Pengawetan dilakukan dengan menggunakan bahan pengawet untuk melindungi kayu dari serangan serangga, jamur, dan organisme lainnya yang dapat menyebabkan kerusakan dan pelapukan kayu. Syarat-syarat yang diperlukan dalam pengawetan kayu adalah :

1. Mempunyai daya racun yang ampuh terhaap organisme perusak kayu

2. Mempunyai daya penetrasi yang tinggi

3. Harus tetap ada dalam kayu selama pemakaian dan tidak mudah tercuci atau menguap.

4. Bahan kimia yang dipakai merupakan persenyawaan yang mantap dan tidak mudah kehilangan daya racunnya

5. Harus aman dipakai dan tidak membahayakan manusia maupun hewan

6. Tidak bereaksi engan bahan yang berhubungan dengannya yang dapat menyebabkan karat atau noda

7. Bersih dalam pemakaian dan tidak mencemari bahan makanan dan lingkungan

8. Kayu yang telah diawetkan harus tetap dapat difinishing (misalnya dicoating) seperti halnya kayu yang tidak diawetkan.

\section{PEMBAHASAN}

\subsection{Permasalahan Konservasi}

1. Sisa-sisa Bahan Konservan Terdahulu

Berdasarkan laporan yang disampaikan oleh juru pelihara bernama Budi Santoso, gapura ini pernah dikonservasi pada tahun 90-an. Informasi tersebut menyebutkan bahwa tindakan konservasi dilakukan dengan proses pembersihan dan perbaikan, kemudian dilanjutkan dengan pelapisan (coating) dengan bahan yang berwarna gelap. Berdasarkan ciri-ciri yang disebutkan 
oleh juru pelihara serta laporan-laporan konservasi BPCB Jawa Tengah, maka diduga kuat bahan coating tersebut adalah “Teak OiP'. Bahan ini banyak digunakan di bidang kerajinan/meubeler, namun sebenarnya kurang cocok untuk permukaan kayu cagar budaya karena akan menyebabkan perubahan warna.

Setelah dilakukan observasi, ternyata sisa-sisa bahan ini masih ada di sebagian permukaan kayu. Selain menyebabkan kayu menjadi kurang menarik, sisa-sisa bahan ini dikhawatirkan akan mengganggu langkah konservasi yang akan dilakukan. Sisa-sisa bahan ini dapat mengurangi daya resap bahan konservan serta daya ikat pelapis. Sisa-sisa bahan pelapis tersebut dapat dilihat pada gambar berikut ( Foto1,2)

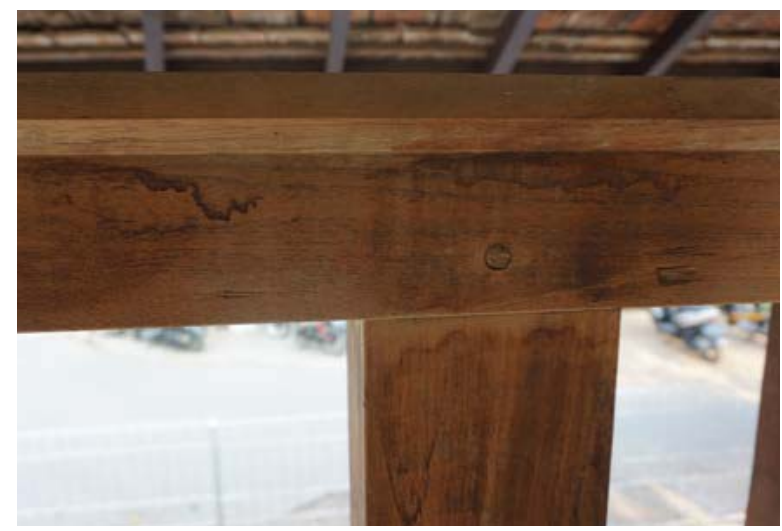

Foto 1

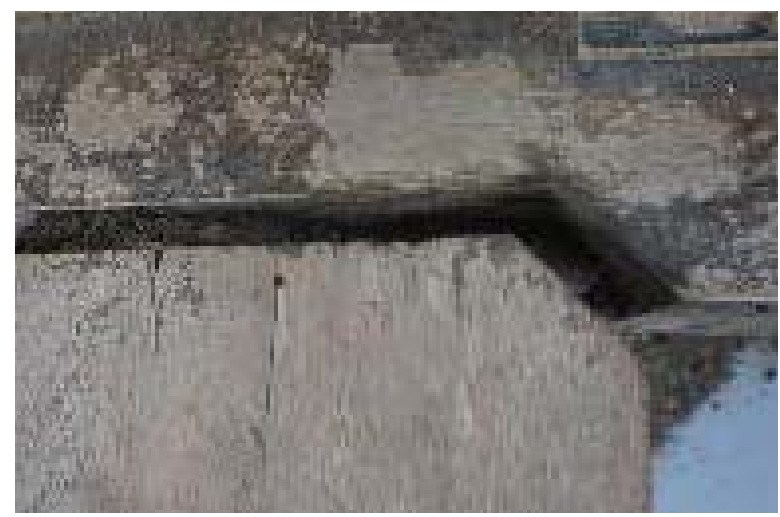

Foto 2

\section{Noda Lilin dari Lebah}

Permasalahan lain yang dihadapi adalah banyaknya noda lilin karena adanya lebah lanceng (Apis trigona) yang bersarang pada celah/lubang yang ada. Lebah lanceng ini berukuran kecil dan tidak memiliki sengat, namun memiliki pola hidup yang mirip dengan lebah pada umumnya yaitu hidup berkoloni dengan membuat sarang dari bahan lilin. Sifat lebah lanceng ini adalah sering membuat titik-titik lilin di sekitar sarangnya sehingga menyebabkan noda-noda pada permukaan kayu yang sulit dibersihkan. Noda ini sebenarnya tidak berbahaya bagi pelapukan kayu, namun mengurangi nilai estetika dari permukaan kayu.

Beberapa noda dapat dilihat pada gambar berikut (Foto 3, 4, 5 ). Noda tersebut cukup tebal karena telah terbentuk sangat lama melalui proses yang sedikit demi sedikit.

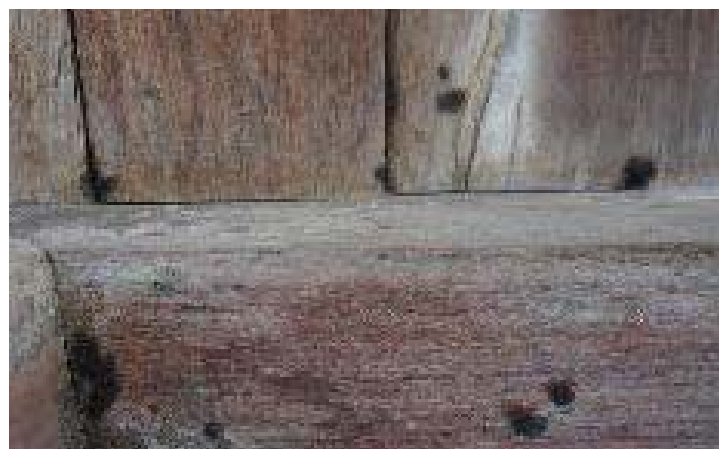

Foto 3

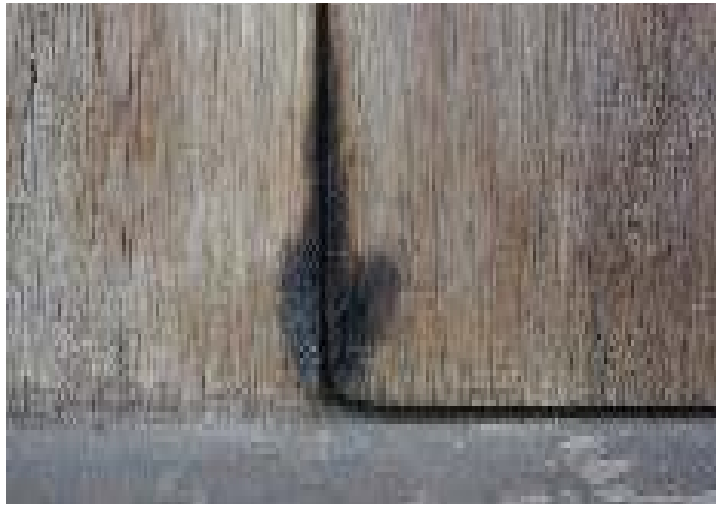

Foto 4

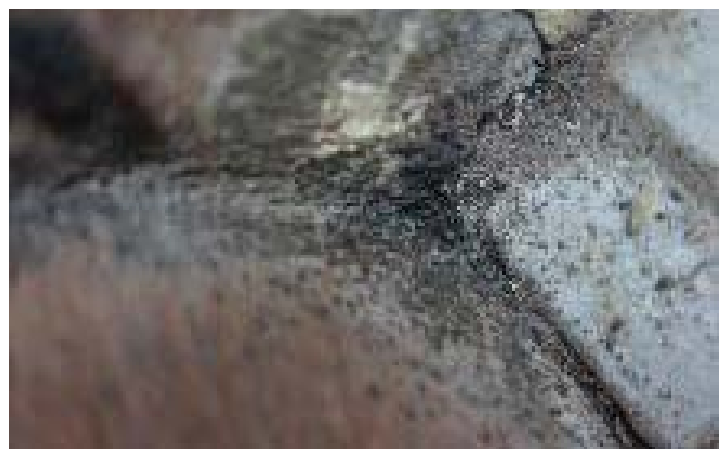

Foto 5

3. Bekas Penanganan Kayu Keropos

Pada saat dilakukan konservasi dan pemindahan gerbang ke dalam bangunan beratap, dilakukan beberapa tindakan perbaikan antara lain terhadap bagian kayu yang keropos. Bagian yang keropos tersebut diisi dengan bahan pengisi dan ditutup dengan campuran serbuk kayu dan lem. Namun sebagian dari perlakuan tersebut kurang sempurna sehingga hasil penambalan kurang baik (Foto 6 ) 


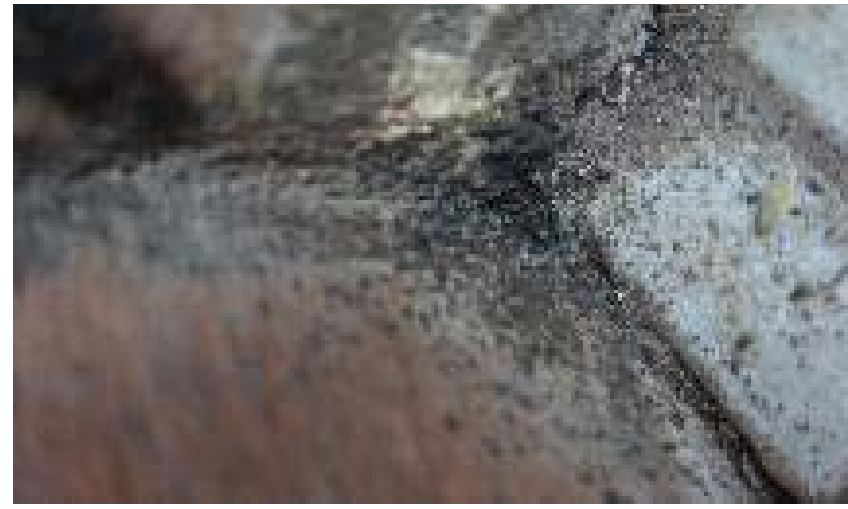

Foto 6

Gambar di atas menunjukkan bagian kaki gapura yang keropos dan telah dilakukan penambalan. Saat ini penambalan tersebut dibuka kembali karena pengisian bagian keropos yang tidak baik. Campuran serbuk kayu dan lem tidak mengeras sempurna serta isian lubang menggunakan bahan yang kurang sesuai (batu, campuran semen, dan lain-lain).

Sementara itu, ada pula bagian kayu keropos yang ditangani dengan cara yang kurang sesuai. Kayu tersebut berada di bagian belakang struktur gapura pada bagian atas. Sekilas terlihat bahwa batang kayu tersebut dilapisi dengan papan triplek. Tindakan ini mungkin dilakukan untuk menutup permukaan kayu yang keropos dan tidak beraturan. Tindakan ini memang dapat menutup kerusakan yang ada, namun tidak menyelesaikan permasalhannya. Saat ini kondisi papan triplek sudah lapuk sehingga diputuskan untuk membuka lapisan tersebut. Setelah dibuka maka dapat dilihat bekas-bekas kayu yang keropos. Hal yang mengkhawatirkan adalah adanya pelapukan baru. Pelapukan baru ini sebelumnya tidak terlihat karena tertutup triplek. Pelapukan baru ini terjadi karena adanya tambahan triplek yang "mengundang" organisme perusak kayu. Bagian dalam triplek merupakan kayu dengan kelas keras dan kelas awet yang rendah. Dalam waktu yang lama, triplek dapat menjadi bahan yang sangat disukai organisme perusak. Pada gambar berikut ini dapat dilihat kondisi kayu yang terlapisi dengan triplek, dan gambar saat lapisan triplek dikupas. Dapat dilihat pada gambar di berikut ini, bahwa setelah dibuka terlihat adanya gejala pelapukan pada kayunya ( Foto 7, 8 ).

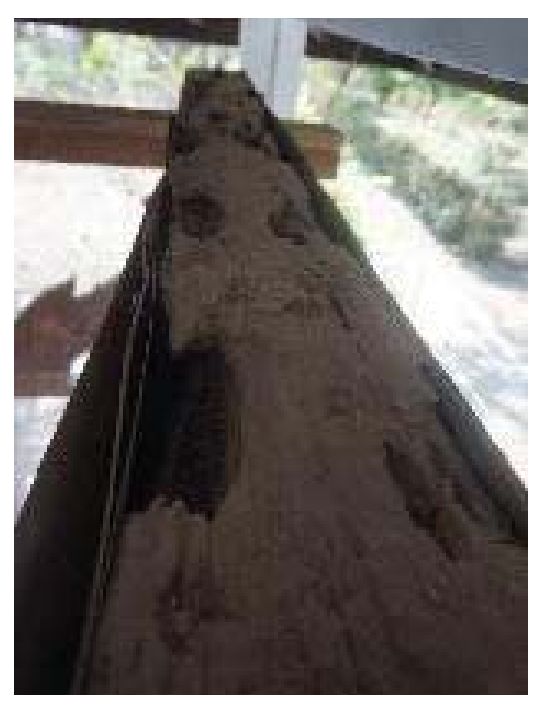

Foto 7

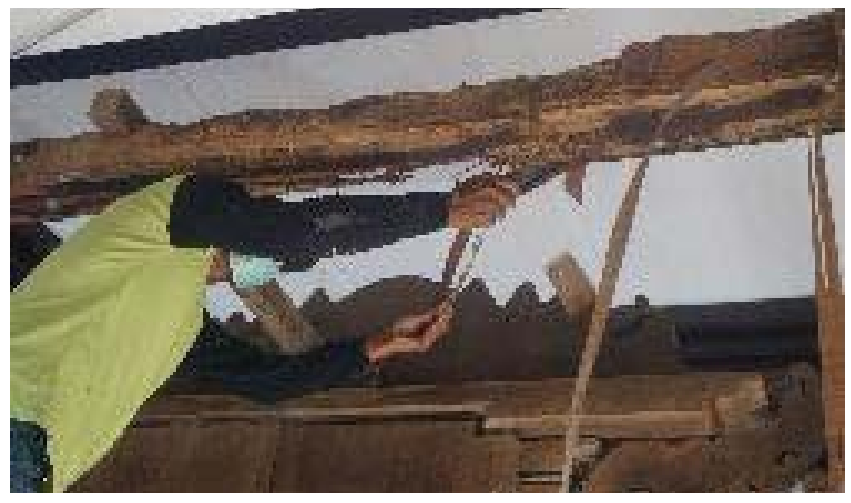

Foto 8

4. Pertumbuhan Organisme

Hasil observasi sebelum dilakukan tindakan konservasi menunjukkan bahwa pertumbuhan organisme yang ada pada permukaan kayu relatif sedikit. Hal ini berkaitan dengan musim, dimana saat dilakukan observasi merupakan musim kemarau sehingga pertumbuhan organisme sangat minim. Meskipun demikian dapat diamati beberapa sisa-sisa pertumbuhan organisme yang ada. Organisme yang terlihat masih aktif namun dalam jumlah yang kecil adalah jamur kerak (Lychenes). Pertumbuhan yang berupa bercak-bercak putih tersebut dapat dilihat pada gambar berikut ini (Foto 9).

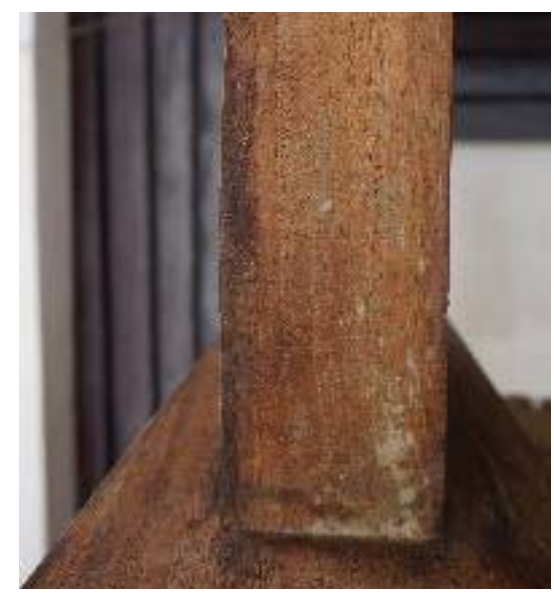

Foto 9 


\section{Vandalisme}

Gambar-gambar di atas menunjukkan adanya vandalisme yang sangat sulit untuk dihilangkan tanpa merusak permukaan kayu. Tulisan tersebut dibuat dengan goresan atau semacam pahatan hingga kedalaman beberapa milimeter. Meskipun demikian, tindakan vandalisme tersebut telah dilakukan cukup lama dan tidak ada vandalisme baru yang dibuat. Juru pelihara telah menjalankan tugas pengamanan dengan baik dan menghapus jika ada corat-coret yang bisa dihapus. Bukti bahwa tindakan vandalisme itu dilakukan di masa lampau adalah beberapa tulisan yang masih menggunakan huruf ejaan lama. Dari gambar di atas kita bisa melihat adanya tulisan dengan ejaan lama yang berbunyi ; HIDAJAT, BANJU-MAS, dan lain-lain ( Foto 10, 11, 12 ).

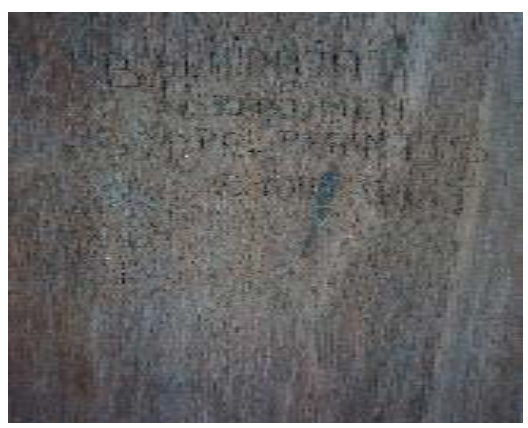

Foto 10

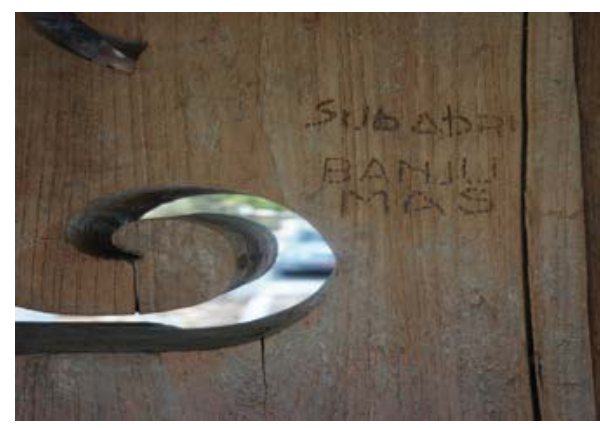

Foto 11

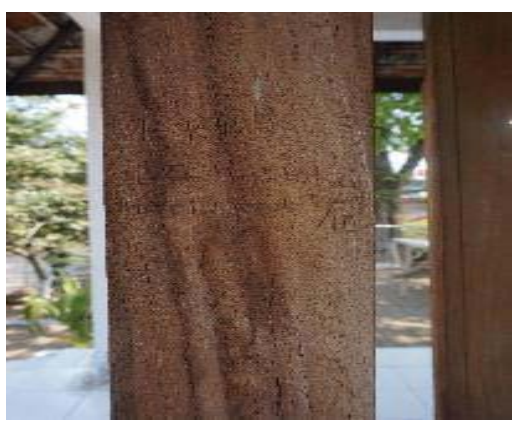

Foto 12
6. Deformasi Struktur

Salah satu permasalahan struktural/konstruksi yang terjadi adalah adanya deformasi pada bagian ornamen atas. Bagian tersebut miring akibat perbedaan beban yang lebih berat di bagian depan. Beban berat di bagian depan ini akibat adanya ornamen kala yang cukup besar sementara di bagian belakang tidak ada. Posisi kemiringan dapat dilihat pada gambar dibawah ini sebelah kiri (Foto 13). Deformasi ini masih bisa tertahan dan tidak runtuh karena masih ada satu batang kayu yang mengikat di bagian belakang (Foto 14). Akibat dari deformasi ini adalah adanya perubahan posisi beberapa bagian gerbang. Salah satunya adalah konstruksi engsel dan beberapa tumpukan kayu yang menjadi renggang (Foto 15). Untuk saat ini deformasi tersebut belum sangat mengkhawatirkan, namun tetap perlu direncanakan tindakan untuk beberapa tahun ke depan.

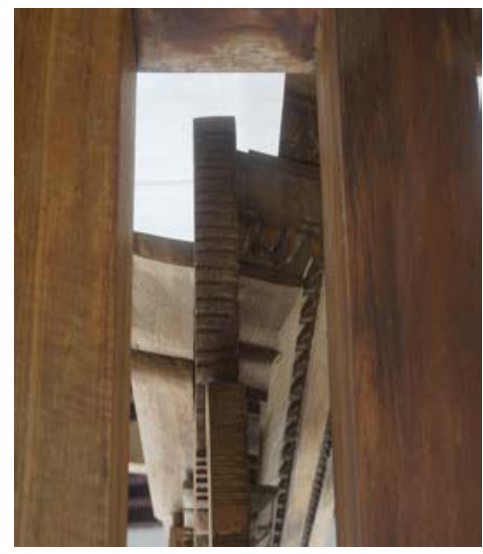

Foto 13

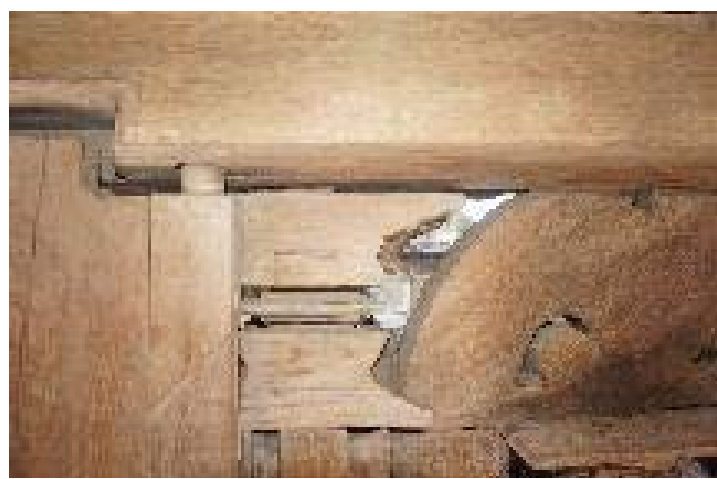

Foto 14

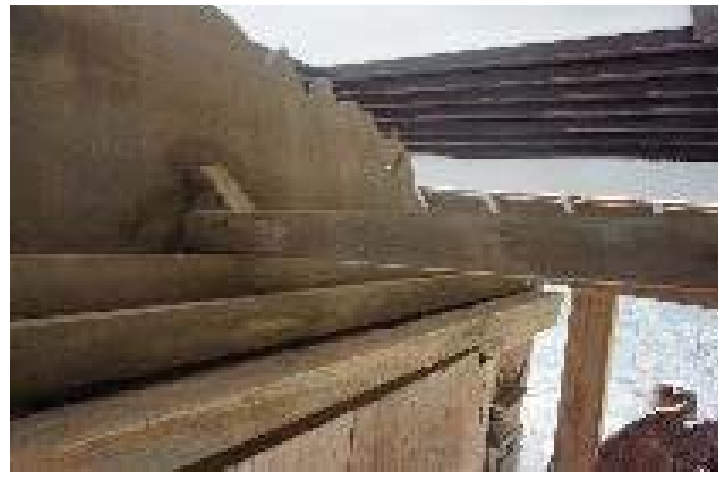

Foto 15

7. Fragmen Lepas

Fragmen lepas adalah bagian/komponen struktur gerbang yang saat ini tidak terpasang pada posisi aslinya. Fragmen ini terutama berasal dari bagian atap gerbang yang saat ini tidak terpasang. Kemungkinan konstruksi atap tersebut sudah tidak lengkap dan sangat sulit untuk dikembalikan seperti semula. Saat ini ditumpuk di dekat bangunan pelindung gerbang (Foto 16). Permasalahan 
yang dihadapi adalah fragmen lepas ini ditempatkan di lokasi yang kurang tepat. Adapun permasalahan yang perlu diambil tindakan ke depan adalah :

- Perbaikan sarana pelindung, jika perlu dibuatkan tempat yang permanen seperti struktur induk gapura.

- Kondisi tumpukan yang tidak rapi dan tidak dikelompokkan.

- Bagian bawah yang terlalu dekat dengan tanah sehingga rawan serangan rayap.

- Penataan yang kurang memperhatikan aspek estetika dan penghormatan terhadap nilai penting fragmen sebagai satu kesatuan dengan gapura.

- Perlu keterangan keterkaitan fragmen dengan gapura, jika perlu bisa ditunjukkan foto gapura lama yang masih memiliki struktur atap asli.

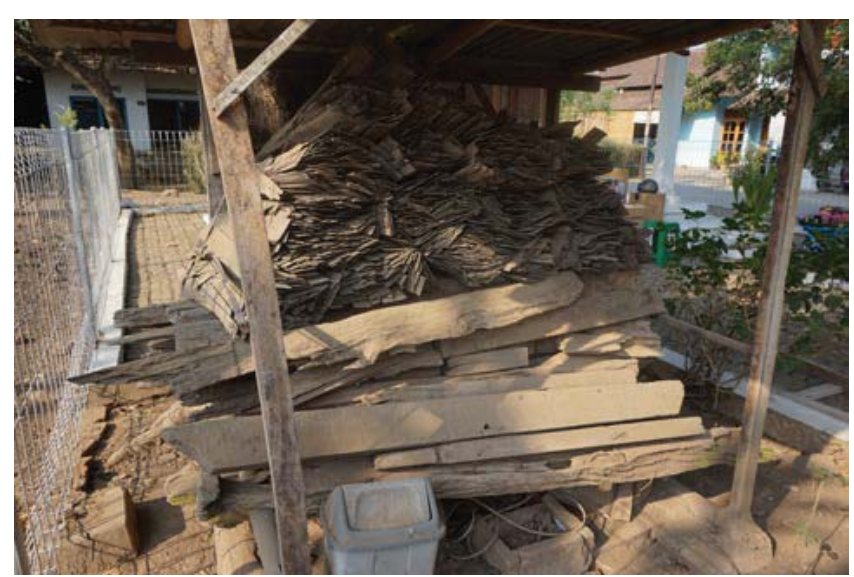

Foto 16

\subsection{Uji Penanganan}

Cagar budaya merupakan kekayaan bangsa yang sangat bernilai tinggi dan langka. Oleh karena itu kerusakan harus dihindari untuk kelestarain jangka panjang, terlebih kerusakan yang disebabkan oleh perlakuan yang tidak tepat. Menurut Undang-Undang Nomor 11 tahun 2010 tentang Cagar Budaya, pasal 53 ayat 1 yang berbunyi "Pelestarian Cagar Budaya dilakukan berdasarkan hasil studi kelayakan yang dapat dipertanggungjawabkan secara akademis, teknis, dan administratif". Oleh karena itu sebelum melakukan tindakan terhadap objek menggunakan bahan dan metode tertentu, harus diujicoba sehingga dapat diketahui efektivitas dan dampaknya. Berikut ini adalah beberapa uji coba pra treatmen yang dilakukan pada konservasi Gapuran Majapahit di Pati.

\section{Pembersihan Lilin Lebah}

Lapisan lilin lebah ini termasuk sulit untuk dihilangkan, karena cukup tebal, liat, dan melekat dengan kuat pada permukan kayu. Uji yang dilakukan adalah dengan beberapa tahap permbersihan (Foto, 17, 18, 19, 20) sebagai berikut :

- Permukaan lilin dikerok dengan hati-hati hingga lapisan lilin menipis. Diusahakan setipis mungkin namun tidak sampai mengenai permukaan kayu.

- Setelah lapisan menipis dilakukan pembersihan menggunakan pelarut. Pertama kali permukaan lilin yang telah tipis ditempel dengan kain/kapas yang telah dibasahi dengan pelarut toluena. Ditunggu beberapa saat hingga lilin melunak.

- Setelah lunak dilakukan pembersihan dengan menggosok lilin dengan kain yang dibasahi dengan pelarut.

- Hal ini dilakukan berulang-ulang hingga sebersih mungkin.

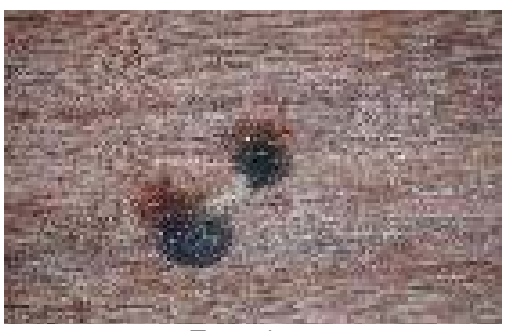

Foto 17

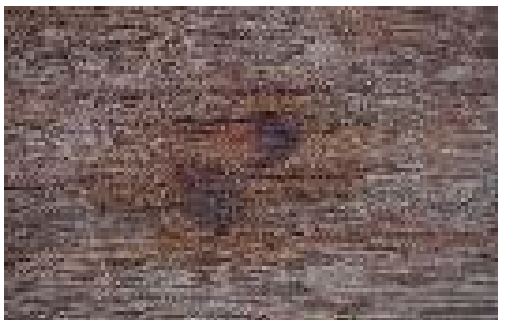

Foto 18

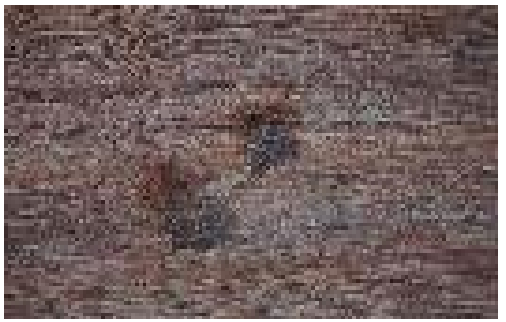

Foto 19

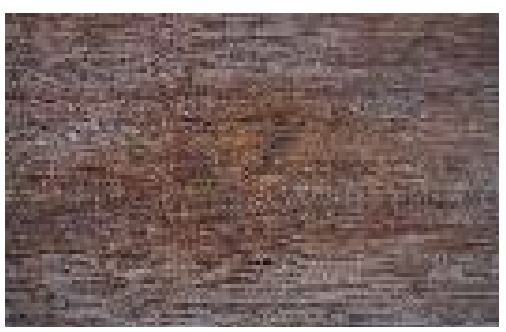

Foto 20 


\section{Pembersihan Sisa Konservan}

Sisa-sisa konservan lama perlu dibersihkan agar tidak mengganggu proses konservasi. Pembersihan dilakukan dengan menggosok sisa bahan dengan kain yang dibasahi dengan pelarut. Pelarut yang dicoba adalah alkohol dan toluena. Berdasar pengujian toluena lebih efektif membersihkan sehingga dapat digunakan (Foto 21, 22, 23).

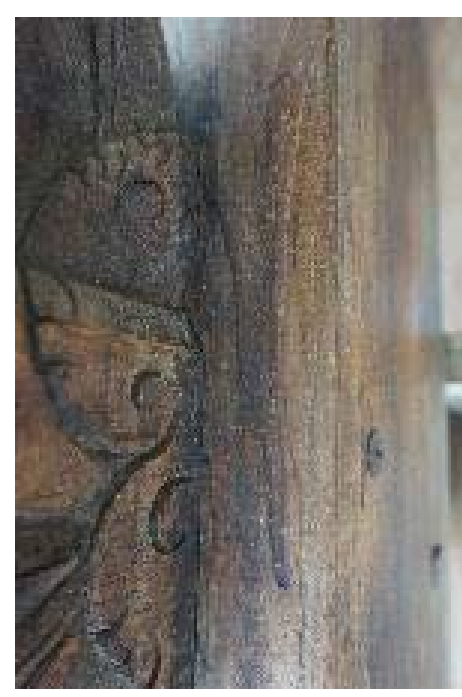

Foto 21

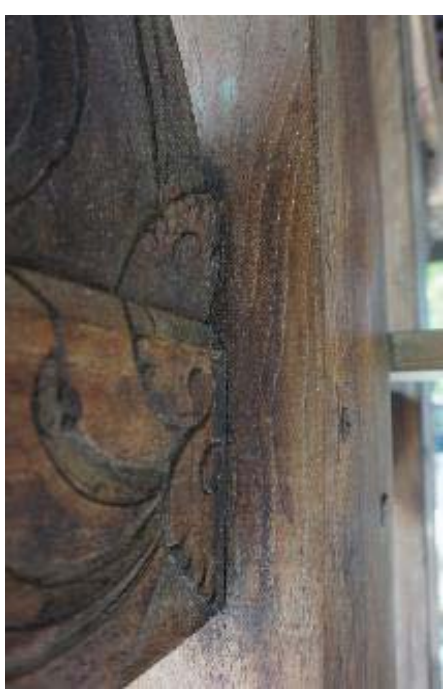

Foto 22

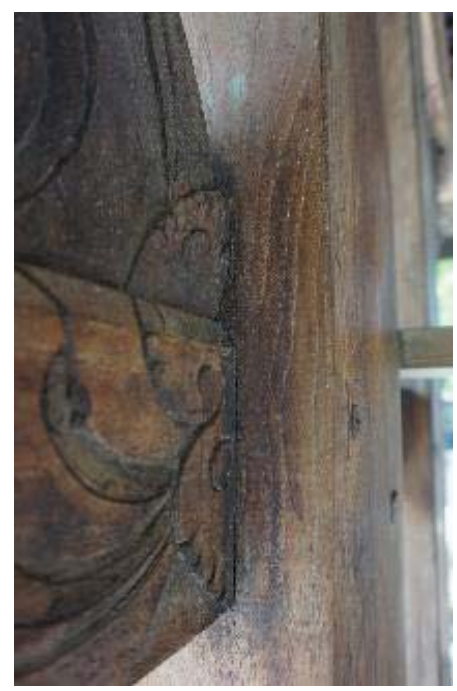

Foto 23
3. Uji Perubahan Warna oleh Pelarut

Dari beberapa uji dan rencana aplikasi bahan yang akan dilakukan, maka penggunaan pelarut toluena banyak dilakukan. Oleh sebab itu perlu dilakukan pengujian untuk memastikan bahwa toluena tidak meninggalkan bekas atau menyebabkan perubahan warna. Hal ini perlu dilakukan karena toluena merupakan pelarut yang relaatif tidak mudah menguap sehingga membutuhkan waktu cukup lama untuk sepenuhnya hilang dari kayu. Berdasar uji yang dilakukan toluena tidak menyebabkan perubahan warna. Perbedaan warna hanya terjadi saat masih basah, dan setelah toluena menguap warna kayu kembali seperti semula (Foto 24).

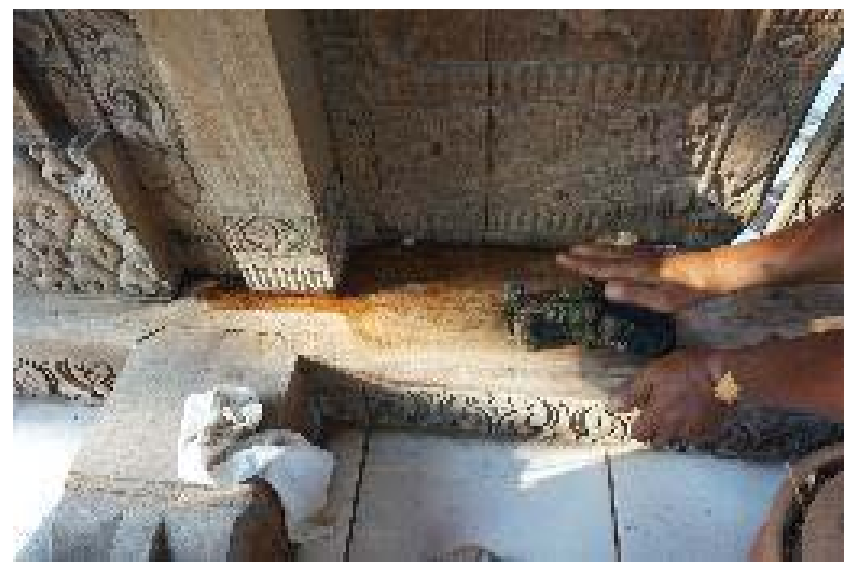

Foto 24

\subsection{Rencana Pelaksanaan Konservasi}

Berdasarkan observasi permasalahan dan uji penanganan yang telah dilakukan maka disusunlah rencana pelaksanaan. Rencana pelaksanaan ini sesuai dengan permasalahan yang ada dan ketersediaan bahan yang telah direncanakan. Metode yang dipilih lebih banyak menggunakan bahan kimia, tidak menggunakan metode berbasis tradisional. Hal ini dilakukan karena beberapa pertimbangan, yaitu :

1. Pelaksanaan konservasi sudah cukup lama tidak dilakukan, sehingga cukup banyak permasalahan konservasi yang terjadi.

2. Frekuensi pelaksanaan konservasi cukup jarang, sedangkan konservasi dengan bahan tradisional menuntut tindakan rutin (umumnya setiap tahun).

3. Bahan-bahan yang tersedia cukup memadai dan kualitasnya juga cukup baik, sehingga diharapkan hasil konservasinya juga akan baik dan bertahan lama.

Selain mempertimbangkan hal-hal di atas, rencana pelaksanaan juga disusun berdasar tinjauan pustaka yang telah diuraikan sebelumnya. Urutan rencana pelaksanaan yang akan dilakukan adalah sebagai berikut :

1. Persiapan alat, bahan dan lokasi

2. Identifikasi pelapukan dan kerusakan serta uji coba beberapa teknik 
3. Pembersihan manual kering

4. Pembersihan sisa konservan dengan pelarut

5. Perbersihan noda lilin

6. Perbaikan bekas penanganan keropos

7. Treatment anti jamur dan bakteri

8. Treatment bahan anti rayap

9. Pelapisan

\subsection{Pelaksanaan Konservasi}

Berdasarkan urutan kegiatan yang direncanakan di atas, maka dilakukan tindakan konservasi.

1. Pembersihan manual kering

Pembersihan kering manual dilakukan dengan alat-alat sederhana untuk menghilangkan debu serta kotoran yang menempel. Alat yang digunakan adalah kuas, sikat kecil, sikat gigi, dan lap kering. Pembersihan ini sekaligus membersihkan sisa-sisa penanganan pada konservasi terdahulu yang kurang baik. Misalnya penghilangan bahan kamuflase pada retakan atau lubang keropos yang kurang baik dan perlu diganti yang baru (Foto 25, 26).

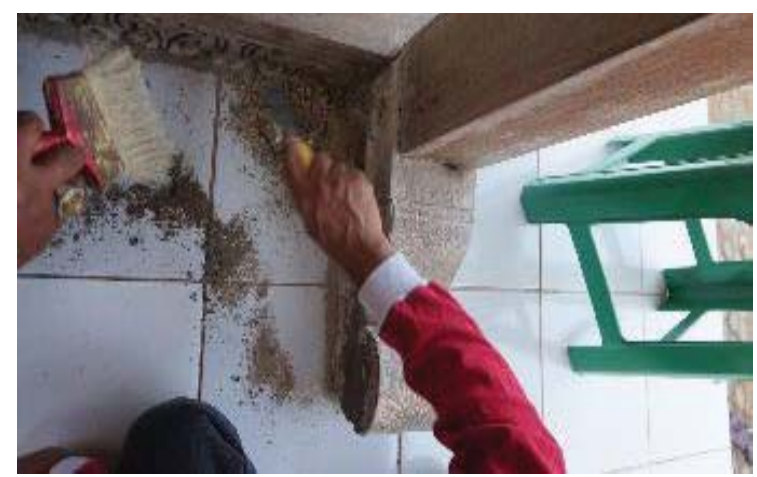

Foto 25

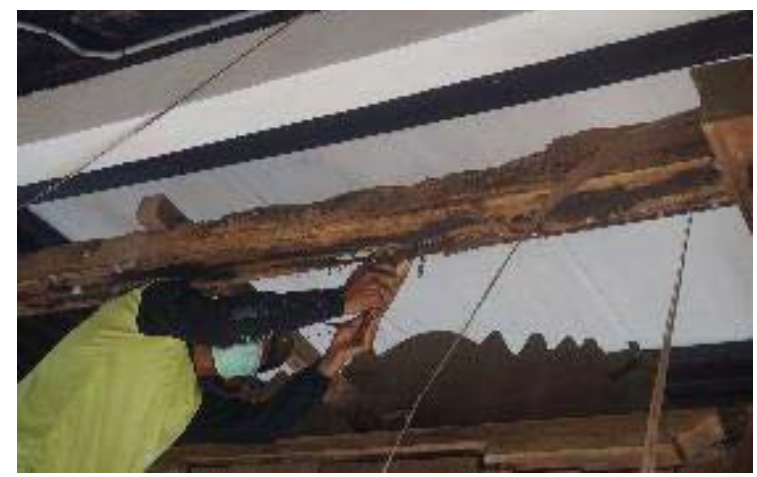

Foto 26

2. Pembersihan sisa konservan dengan pelarut

Pembersihan sisa konservan dengan pelarut ini sangat penting untuk dilakukan, karena jika masih ada dapat menghalangi masuknya bahan konservan yang akan diaplikasikan. Pembersihan menggunakan pelarut toluena yang telah diuji sebelumnya dan dinilai cocok untuk proses penghilangan ini. Cara pembersihannya adalah dengan pengolesan menggunakan kuas dan pada saat yang sama segera di lap dengan kain lap yang kering sehingga pelarut dapat terambil bersama dengan lapisan bahan yang akan dihilangkan (Foto 27).

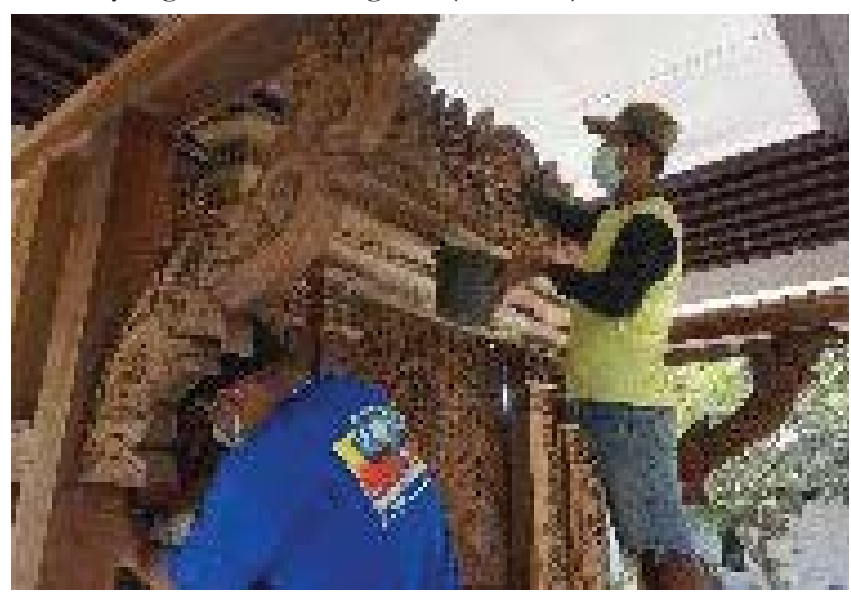

Foto 27

3. Perbersihan noda lilin

Pembersihan noda lilin dilakakukan dengan metode yang telah diuji sebelumnya. Pembersihan ini membutuhkan waktu yang cukup lama karena cukup banyak dan tersebar pada beberapa titik.

4. Perbaikan bekas penanganan keropos

Bagian keropos yang pernah dikonservasi saat ini kondisinya sudah kurang baik, sehingga perlu perbaiki dan diganti dengan bahan baru. Pada beberapa bagian kaki, penambalan keropos menggunakan bahan yang kurang baik sehingga tidak bisa mengeras sempurna hingga saat ini, selain itu juga ada pengisian dengan bahan yang tidak sesuai. Bahan tersebut dikupas dan selanjutnya bisa diganti dengan bahan pengisi baru (Foto 28).

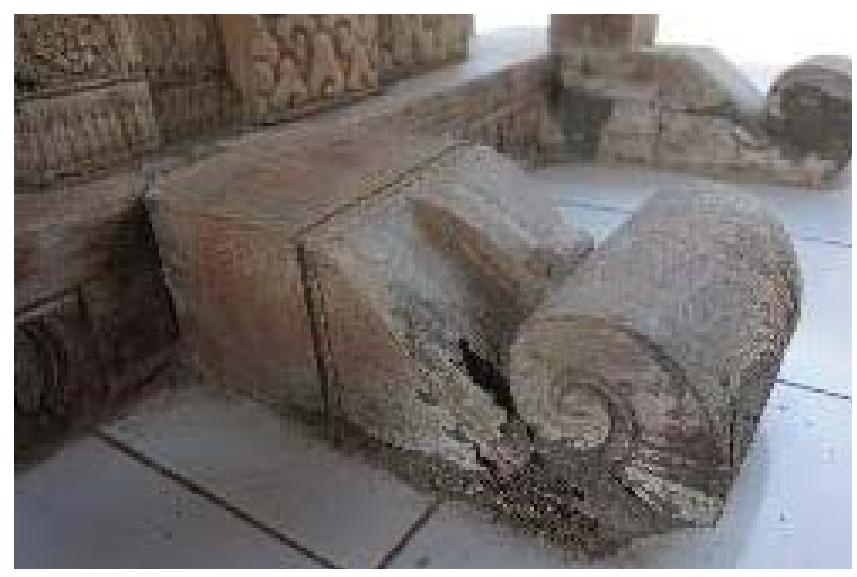

Foto 28 
Adapun bagian kayu yang tertutup dengan triplek yang telah rusak kemudian dikupas sehingga bisa dilanjutkan dengan tindakan yang sesuai (Foto 29).

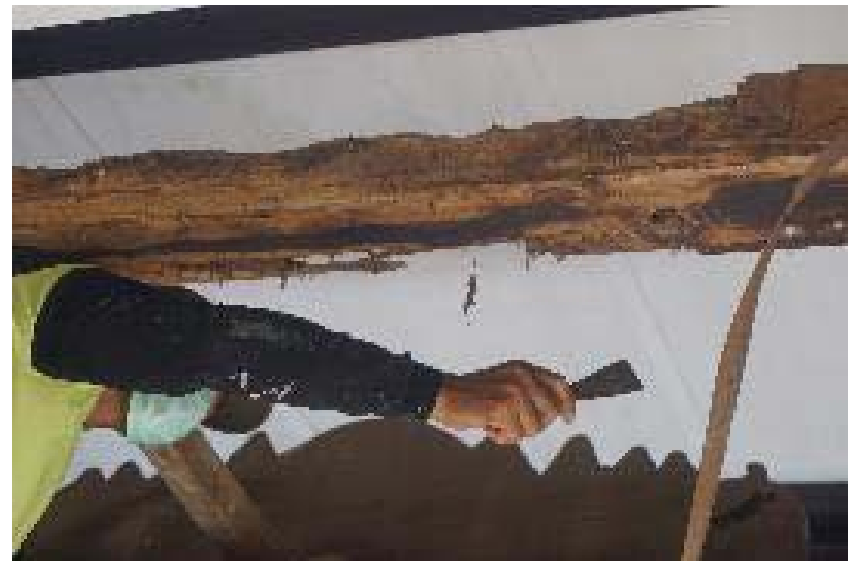

Foto 29

5. Treatment anti jamur dan bakteri

Treatmen jamur dan bakteri dilakukan secara lokal pada bagian yang terdapat pertumbuhan jasad tersebut. Treatmen dilakukan dengan bahan yang dapat mematikan jamur dan bakteri. Bahan yang digunakan adalah alkohol yang diaplikasikan dengan cara dioles, atau digosok pada bagian-bagian yang diperlukan. Alkohol yang digunakan berkadar 70\%, karena kadar ini adalah kadar yang tepat sebagai desinfektan.

\section{Treatment bahan anti rayap}

Anti rayap sangat dibutuhkan karena gapura ini langsung bersentuhan dengan lantai, meskipun bukan tanah langsung namun rayap masih sangat mungkin untuk naik dan menyerang. Selain itu rayap kayu kering juga dapat menyerang jika tidak ada bahan anti rayap dalam kayu. Bahan antirayap yang digunakan adalah Stedfast, yang merupakan bahan anti rayap yang ada di pasaran.

\section{Pelapisan}

Pelapisan merupakan tahap akhir dari kegiatan konservasi ini. Dengan adanya pelapis maka diharapkan permukaan kayu menjadi lebih terlindungi dan dapat bertahan lebih lama. Bahan pelapis yang digunakan adalah Paraloid B-72 dengan pelarut toluena. Bahan ini merupakan bahan yang lazim digunakan dalam kegiatan konservasi material cagar budaya terutama sebagai bahan pelapis dan bahan konsolidan. Hasil pelapisan dengan Paraloid umumnya cukup baik dan mampu bertahan cukup lama. Warna yang dihasilkan juga cukup natural, kecuali penggunaan dengan kadar yang terlalu tinggi dapat menyebabkan objek menjadi lebih mengkilap. Dalam pengerjaan pelapisan pada kayu gapura ini hasilnya cukup baik dan tidak memberikan warna yang tidak natural.

\section{PENUTUP}

Kegiatan konservasi Gapura Majapahit di Pati yang merupakan bekas gerbang keputren Majapahit telah selesai dilaksanakan. Pelaksanaan konservasi telah mengikuti tahapan-tahapan yang diperlukan agar tindakan yang dilakukan dapat efektif dan tidak menimbulkan dampak negatif. Tahapan analisis permasalahan dan pengujian terhadap bahan dan metode yang akan digunakan sangat penting untuk semua pelaksanaan kegiatan konservasi. Hal ini sesuai dengan peraturan perundang-undangan yang mensyaratkan agar tindakan konservasi dapat dipertanggungjawabkan secara ilmiah. Kegiatan konservasi yang telah dilakukan diharapkan dapat menyelesaikan berbagai permasalahan dan membuat kondisi material dapat bertahan lebih lama. Konservasi dengan bahan-bahan kimia yang digunakan diharapkan dapat bertahan lebih lama sehingga tidak perlu pengulangan-pengulangan yang terlalu sering. Tindakan yang diharapkan ke depan adalah pembersihan secara manual terhadap permukaan dan lingkungan sekitarnya.

Rekomendasi yang perlu disampaikan untuk tindakan ke depan adalah perlunya dilakukan tindakan konservasi dan penataan koleksi lepas. Saat ini koleksi lepas tersebut ditumpuk dengan posisi yang kurang baik, serta atap pelindung yang kurang sempurna. Mengingat koleksi lepas tersebut adalah bagian penting dari gapura, terutama bagian atap maka sangat penting untuk dilestarikan. Gambar asli saat masih ada atapnya saat ini masih bisa diperoleh meskipun kurang jelas. Dengan adanya komponen yang masih cukup banyak, maka ada kemungkinan konstruksi atap tersebut masih bisa dipasang kembali meskipun perlu kajian tersendiri. Rekondisi lain yang perlu dilakukan adalah perkuatan bagian ornamen yang miring, karena dikhawatirkan dalam jangka panjang akan semakin miring dan membahayakan. 


\section{DAFTAR PUSTAKA}

Cahyandaru N, Parwoto, Arif Gunawan, (2010), Konservasi Cagar Budaya Berbahan Kayu dengan Bahan Tradisional, Balai Konservasi Borobudur

Dumanauw. JF, (1982) Mengenal Kayu, Penerbit PT. Gramedia, Jakarta

Nandika. D, Rismayadi. Y, Diba. F, (2003), Rayap Biologi dan Pengendaliannya, Muhammadiyah University Press, Surakarta.
Sosrosumarto K.M, Dibyasudira S., (1980), Kitab Babad Pati, Departemen Pendidikan dan Kebudayaan Republik Indonesia

Suranto Y, (2015), Studi Diagnostik Konservasi Tempat Tidur Etnik Madura Koleksi Museum Kayu Wanagama I, Jurnal Konservasi Cagar Budaya Borobudur, Volume 9, Nomor 1

Plendrleith, H.J., 1957, The Conservation of Antiquites and Work of Art, Oxford University Press, London 